\title{
IMMUNOEXPRESSION OF Ki-67 AND CYCLOOXYGENASE-2 IN ODONTOGENIC KERATOCYST AND DENTIGEROUS CYST: A COMPARATIVE STUDY
}

\author{
Enas Alaa Eldin Abd El-Aziz *
}

\begin{abstract}
Aims: To evaluate the expression of Cyclooxygenase-2 (COX-2) in odontogenic keratocyst $(\mathrm{OKC})$ and dentigerous cyst and correlate it with $\mathrm{Ki}-67$ expression in these lesions.

Material and Methods: This study was carried out on 32 paraffin embedded specimens of dentigerous cyst and OKC. 16 samples obtained from healthy mucosa served as controls. Slides prepared from paraffin-embedded sections were immunohistochemically stained for Ki-67 and COX-2 and immunoreactivity of the two markers was evaluated using index of positivity and staining intensity. Statistical analysis was performed using Mann-Whitney and Spearman's correlation tests.
\end{abstract}

Results: Ki-67 and COX-2 expression in OKC and dentigerous cyst was found to be significantly higher than those observed in healthy mucosa groups $(\mathrm{p}<0.05)$. The expression of the two markers was significantly higher in $\mathrm{OKC}$ than in dentigerous cyst. A positive correlation was found between the two markers in both lesions.

Conclusions: Increased expression of $\mathrm{Ki}-67$ and COX- 2 in $\mathrm{OKC}$ is an indicator of the high mitotic activity of these lesions compared with dentigerous cyst. COX-2 is implicated in odontogenic epithelial proliferation in $\mathrm{OKC}$ and dentigerous cyst.

Key words: Ki-67, COX-2, OKC, dentigerous cyst.

\section{INTRODUCTION}

Odontogenic cysts are those arising from epithelium involved in tooth development. They differ significantly in their incidence, clinical behavior, histological architecture and consequently treatment options (Regezzi et al, 2008).

Because of its specific histological and clinical characteristics, odontogenic keratocyst (OKC) was classified as a cystic odontogenic neoplasm and the term keratocystic odontogenic tumor was used (Philipsen, 2005). However recently, it has been categorized as an odontogenic cyst according to World Health Orgaization (WHO) 2017 (Adel et al, 2017).

\footnotetext{
* Lecturer of Oral and Maxillofacial Pathology, Faculty of Dentistry, Minia University.
} 
On the other hand, dentigerous cyst accounts for $20 \%$ of oral developmental cyst and is considered the most common developmental cyst in the oral cavity (Shibata et al, 2004). It has a low recurrence rate. However, longstanding lesions can produce local destruction, bony expansion, root resorption, or displacement of teeth (Kolokythas et al, 2012). The epithelium of dentigerous cyst may show neoplastic transformation into ameloblastoma, squamous cell carcinoma or intraosseous mucoepidermoid carcinoma (Neville et al, 2009).

Despite being both derived from odontogenic epithelium, there is great difference in developmental mechanism, biological behavior and treatment management of OKC and dentigerous cyst. Therefore, identifying the mechanisms underlying the lesion growth and behavior has been matter of concern (Maryam et al, 2015).

COX-2 is a cytokine inducible enzyme involved in the synthesis of prostaglandins (PGs) from arachidonic acid (Zha et al, 2004).

Under basal conditions, COX-2 expression is highly restricted; however, COX-2 is dramatically upregulated during inflammation (Crofford, 1997).

Several studies have detected significant COX-2 overexpression in a wide range of preneoplastic and malignant conditions including colorectal cancer, stomach, esophagus, breast, prostate and head and neck carcinomas (Castealo et al,2003; Davies, 2003; Hussain et al, 2003; Manchana et al, 2006; Itoh et al,2003; Kanekura et al, 2000; Kawai et al, 2002; Li et al, 2004; Masunaga et al, 2000; Miyata et al, 2003; Nozoe et al, 2005).

The exact mechanisms by which COX-2 encourages tumorigenesis include synthesis of PGs which stimulate PGs receptors with subsequent stimulation of cellular proliferation, induction of angiogenesis, inhibition of apoptosis, and stimulation of invasion/ motility by adjustment of cell adhesion molecules (Telliez et al, 2006).
Moreover, COX-2-dependent prostaglandin release can suppress antigen presentation and immune activation in cancer (Greenhough et al, 2009).

$\mathrm{Ki}-67$ is a nuclear protein that can be detected in all proliferating cells, whereas resting, non-cycling cells (G0 phase) lack Ki-67 expression. It is usually used in research studies as an independent prognostic marker of tumor proliferation to investigate the growth characteristics of the lesion (Adelsperger et al, 2000)

The aim of the present study is to evaluate the expression of COX-2 in both $\mathrm{OKC}$ and dentigerous cyst and correlate it with the epithelial proliferation in these lesions.

\section{MATRIAL AND METHODS:}

\section{Case selection:}

A total of 32 paraffin blocks (16 dentigerous cysts and $16 \mathrm{OKC}$ ) were retrieved from the archives of Oral and Maxillofacial Pathology Department, Faculty of Dentistry, Minia University. Clinical records for the patients were reviewed and information was gathered regarding age, gender and location of the lesions. A four micron section was cut from each block, stained with Hematoxylin and Eosin (H\&E) staining and re-examined for confirmation of the diagnosis. The control group included 16 samples which were harvested from healthy mucosa taken by punch biopsy from operculum covering upper or lower wisdom. Considering the effect of inflammation on the expression of COX-2, in this study, non-inflammatory samples were used.

\section{Immunohistochemical staining}

It was performed using the standard method (avidin biotin peroxidase) (Bratthauer, 2010). Paraffin blocks were cut into $4 \mu \mathrm{m}$ thick and mounted on positively charged glass slides (Optiplus, Biogenex, Milmont Drive, CA, USA) for 
immunostaining with anti-Ki-67 and anti-COX-2 antibodies.

The paraffin embedded tissue sections on positively charged slides were deparaffinized in xylene, rehydrated through graded alcohols to water and treated with endogenous peroxidase in $0.3 \% \mathrm{H}_{2} \mathrm{O}_{2}$ for 30 min to block the endogenous peroxidase activity. For antigen retrieval, the slides were boiled in $10 \mathrm{mM}$ citrate buffer, $\mathrm{pH} 6.0$ for 10 $20 \mathrm{~min}$ followed by cooling at room temperature for $20 \mathrm{~min}$. The sections were then incubated with the primary monoclonal mouse antihuman Ki67 antibody (clone MIB-1, IS626, Ready to use, Dako, Denemark) and the primary antibody rabbit polyclonal anti-COX2 antibody (Thermo Scientific, Lab vision, Kalamazoo, MI, USA) with dilution of 1/500 for $30 \mathrm{~min}$ at room temperature in a humified chamber. After washing with phosphate buffer solution (PBS), the slides were treated with the biotin labeled link antibody and then the streptavidin conjugated horse radish peroxidase was used.

The diaminobenzedine chromogen was applied to visualize the antigen antibody reaction. All these reagents belong to the universal Labeled Streptavidin-Biotin 2 System, Horseradish Peroxidase (code no.K0673 DakoCytomation, Glostrup, Denmark). All the slides were immersed in Mayer's hematoxylin for counter staining. Finally, the sections were covered by cover slips using aqueous mounting medium. Negative controls were stained in the same technique but with omitting of the primary antibody and treating them with PBS instead.

\section{Immunohistochemical evaluation}

The ordinary light microscope (Leica, Germany) was used to detect and localize the immunostaining of the two antibodies. For Ki-67, cells with nuclear staining were considered positive while cells with cytoplasmic staining were considered positive in case of COX-2 antibody.
Five random fields in each specimen were captured using magnification (X400). Photomicrographs were captured using a digital camera (Leica, Germany) mounted on the light microscope.

Immunohistochemical analysis followed the semi-quantitative markers expression in the epithelial compartments of the lesions. It was calculated as an index of positivity (IP) for each used biomarker by reporting the number of marked cells by the total number of 500 cells identified at magnification of $\mathrm{X} 400$, followed by multiplying the result by 100 . The percentage of positively stained cells in representative high power (X400) fields was determined and scored as follows: 0 , no identified staining of the odontogenic epithelium or unnoticeable staining; $1,<10 \%$ staining; 2,10 50\% staining; and 3,>50\% staining (Barboza et al, 2005).

Also the staining intensity was assessed using image analysis software (Image J, 1.41a, NIH, USA) and rated on a scale from 0 to 3 as follows: 0 , no staining at all; 1 , weak staining; 2 , moderate staining; and 3, strong staining.

Degree of immunoreactivity was obtained by the sum of score of IP and staining intensity score with a maximum score of 6 . A final score of 0 was regarded as negative, 2 as weak, 3 or 4 as mild, and 5 or 6 was considered as strong immunoreactivity (Mohammed et al, 2017).

\section{Statistical analyses}

The Statistical Package for the Social Sciences (SPSS) 19.0 software (IBM SPSS, Armonk, NY, USA) was used for analyzing the results. Quantitative data were presented by mean, standard deviation and range. Mann-Whitney U test was used to compare differences between two independent groups. The correlation between the Ki-67 and COX-2 expression in dentigerous cyst and $\mathrm{OKC}$ was assessed using Spearman rank correlation analysis. 
The difference between groups was considered statistically significant at $P \leq 0.05$.

\section{RESULTS}

\section{Clinical data}

This study has been carried out on 48 specimens (16 dentigerous cysts, 16 OKC and 16 healthy mucosa) available for study at the archives of the Department of Oral and Maxillofacial Pathology, Minia University. Clinicopathological data of the lesions are summarized in table 1.

TABLE (1) Clinicopathological characteristics of the involved specimens

\begin{tabular}{|l|c|c|c|}
\hline Group (n=16) & Total & OKC & $\begin{array}{c}\text { Dentigerous } \\
\text { cyst }\end{array}$ \\
\hline $\begin{array}{l}\text { Age (years) } \\
\text { Mean } \\
\text { Range }\end{array}$ & 31.2 & 28.3 & 32.6 \\
\hline $\begin{array}{l}\text { Gender n (\%) } \\
\text { Male }\end{array}$ & $21-57$ & $21-45$ & $24-57$ \\
$\quad \begin{array}{l}\text { Female } \\
\text { Location, n (\%) } \\
\text { Maxilla } \\
\text { Mandible }\end{array}$ & $17(53.1 \%)$ & 7 & 10 \\
\hline
\end{tabular}

\section{Ki-67 protein expression}

Ki-67 protein expression was detected as yellowish-brown nuclear staining in the epithelial cells of dentigerous cysts and OKC.

Ki-67 positive staining was detected in 28 cases including 13 cases of dentigerous cyst and 15 cases of $\mathrm{OKC}$.

In dentigerous cyst, positive cells were mainly found in the basal and suprabasal layers (Figure 1). Ki-67 expression was absent in $18.75 \%$, weak in $56.25 \%$, moderate in $25 \%$, and strong in $0 \%$ of odontogenic epithelial cells of the cyst lining (Table 2).
In $\mathrm{OKC}$, positive cells were found mainly in the basal and suprabasal cells layers (Figure 2). Ki-67 expression was negative in $6.25 \%$, weak in $31.25 \%$, moderate in $25 \%$ and strong in $37.5 \%$ (Table 2).

The staining intensity and number of Ki-67 positively stained cells (IP) were higher in OKC than dentigerous cyst.

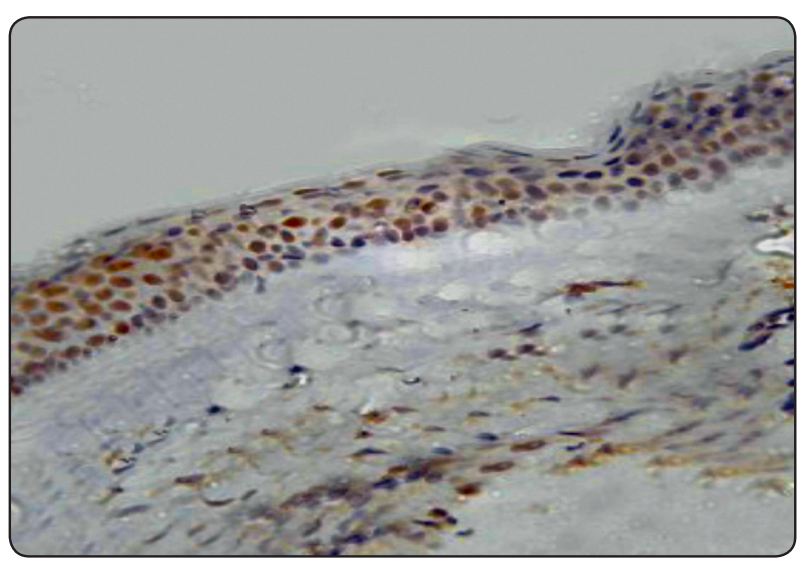

Fig. (1): Photomicrograph of dentigerous cyst showing nuclear staining in the epithelial cells (Anti-Ki-67. Original magnification X400).

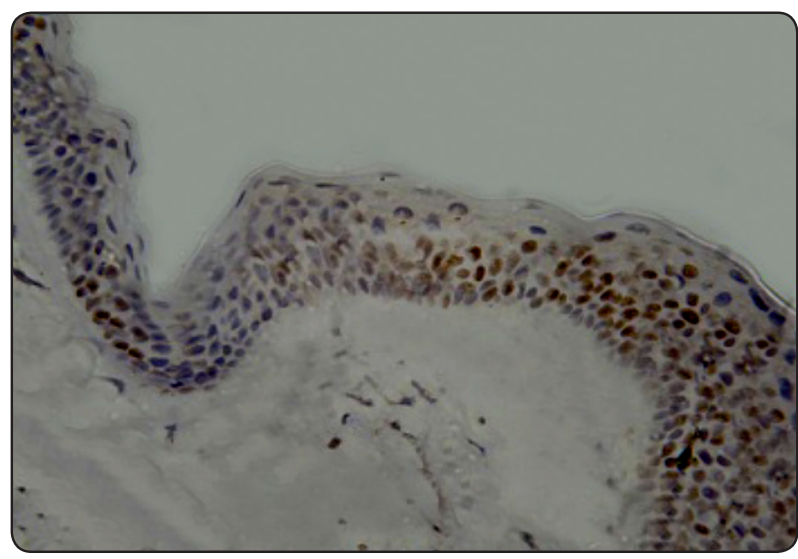

Fig. (2): Photomicrograph of OKC showing nuclear staining in the epithelial cells (Anti-Ki-67. Original magnification X400).

\section{COX-2 protein expression}

COX-2 protein expression was detected as yellowish-brown cytoplasmic staining of different intensities in the epithelial cells of dentigerous cysts and $\mathrm{OKC}$. 


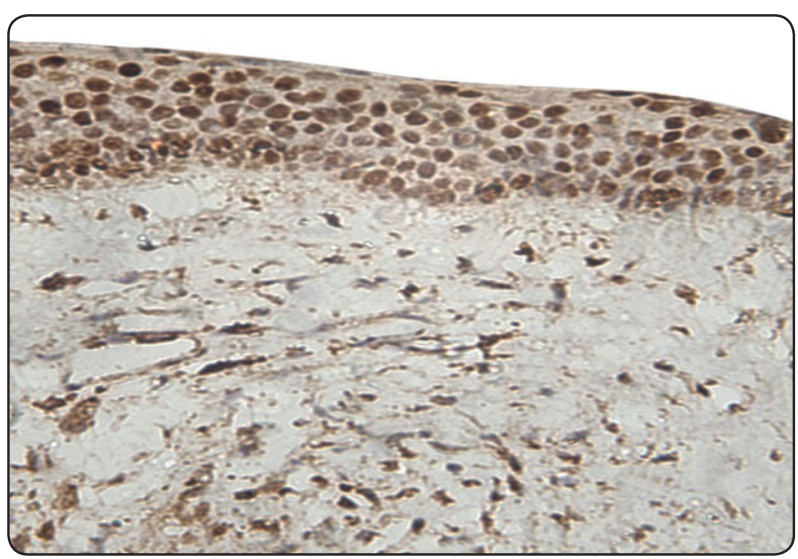

Fig. (3): Photomicrograph of dentigerous cyst showing cytoplasmic staining in the epithelial cells (AntiCOX-2. Original magnification X400).

In dentigerous cysts, positive cells were observed throughout the cystic wall (Figure 3). COX-2 staining intensity was absent in $12.5 \%$, weak in $31.25 \%$, moderate in $56.25 \%$, and strong in $0 \%$ of odontogenic epithelial cells in dentigerous cyst samples (Table 2).

OKC showed diffuse widely distributed COX-

TABLE (2): The immunohistochemical staining of Ki-67 and COX-2 in terms of staining intensity in the study groups

\begin{tabular}{|l|c|c|}
\hline \multicolumn{3}{|c|}{ N(\%) } \\
\hline \multicolumn{1}{|c|}{ Protien } & $\begin{array}{c}\text { Dentigerous cyst } \\
(\mathbf{n = 1 6})\end{array}$ & $\begin{array}{c}\text { OKC } \\
(\mathbf{n = 1 6})\end{array}$ \\
\hline Ki-67 & & $1(6.25 \%)$ \\
Negative (Score=0) & $3(18.75 \%)$ & \\
Positive & & $5(31.25 \%)$ \\
Weak (Score=1) & $9(56.25 \%)$ & $4(25 \%)$ \\
Moderate(Score=2) & $4(25 \%)$ & $6(37.5 \%)$ \\
Strong (Score=3) & $0(0 \%)$ & $0(0 \%)$ \\
\hline COX-2 & $2(12.5 \%)$ & $3(8.75 \%)$ \\
Negative(Score=0) & & $8(50 \%)$ \\
Positive & $5(31.25 \%)$ & $5(31.25 \%)$ \\
Weak(Score=1) & $9(56.25 \%)$ & \\
Moderate(Score=2) & $0(0 \%)$ & \\
Strong(Score=3) & &
\end{tabular}

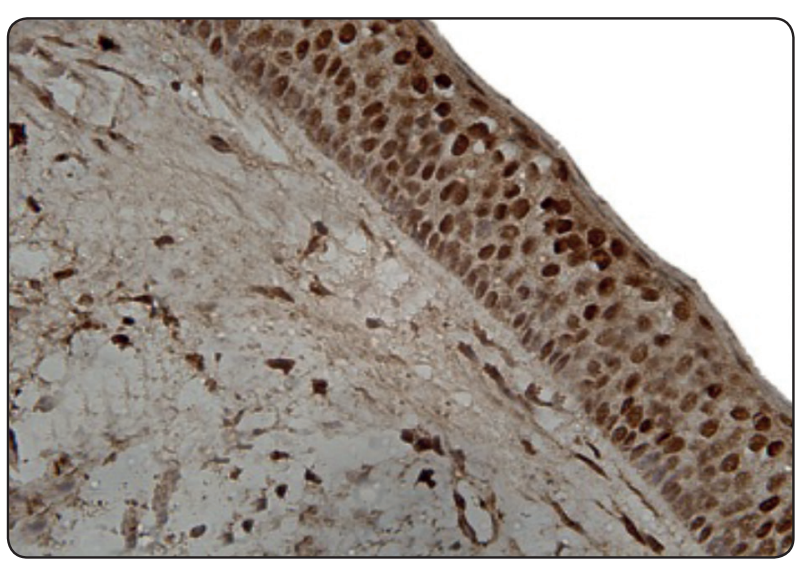

Fig. (4): Photomicrograph of OKC showing cytoplasmic staining in the epithelial cells(Anti-COX-2. Original magnification $\mathrm{X} 400$ ).

2 expression in epithelial cells (Figure 4). COX-2 expression was negative in $0 \%$, weak in $18.75 \%$, moderate in $50 \%$ and strong in 31.25 of $\mathrm{OKC}$ samples.

Higher number of COX-2 positively stained cells and stonger expression were found in $\mathrm{OKC}$ compared to dentigerous cyst.

TABLE (3): The immunohistochemical staining of Ki-67 and COX-2 in terms of Median index of positivity (IP) in the study groups

\begin{tabular}{|c|c|c|}
\hline \multicolumn{3}{|c|}{ No. of cases/ Median IP } \\
\hline Protein & Dentigerous cyst & OKC \\
\hline KI-67 & & \\
$0($ Score=0) & 3 & 1 \\
$<10 \%($ Score=1) & $7(5.2 \%)$ & $3(6.4 \%)$ \\
$10-50 \%($ Score=2) & $4(37.6 \%)$ & $7(42.5 \%)$ \\
$>50 \%($ Score $=3)$ & $2(54.3 \%)$ & $5(77.5 \%)$ \\
\hline COX-2 & & \\
$0($ Score=0) & 2 & 0 \\
$<10 \%($ Score=1) & $2(4.9 \%)$ & $1(8.6 \%)$ \\
$10-50 \%($ Score=2) & $6(33.5 \%)$ & $7(39.8 \%)$ \\
$>50 \%($ Score=3) & $6(57.7 \%)$ & $8(71.2 \%)$ \\
\hline
\end{tabular}




\section{Statistical results}

Ki-67 and COX-2 immunoreactivity (as represented by the sum of score of IP and score of staining intensity) was found to be significantly higher in $\mathrm{OKC}$ and dentigerous cyst in relation to normal oral mucosa as shown in table 4,5 .

TABLE (4): Comparison between normal mucosa group and dentigerous cyst group using Mann-Whitney $U$ test regarding Ki-67 and COX-2 immunoreactivity

\begin{tabular}{|c|c|c|c|}
\hline Total Score & $\begin{array}{c}\text { Normal } \\
\text { mucosa } \\
\text { Mean } \pm \text { SD }\end{array}$ & $\begin{array}{c}\text { Dentigerous } \\
\text { cyst } \\
\text { Mean } \pm \text { SD }\end{array}$ & p-value \\
\hline Ki-67 & $1.31 \pm 1.25$ & $2.37 \pm 1.54$ & 0.05 \\
\hline COX-2 & $1.120 .93 \pm$ & $3.44 \pm 1.63$ & 0.0001 \\
\hline
\end{tabular}

$P$ value is significant when it is $\leq 0.05$

TABLE (5): Comparison between mormal mucosa group and OKC group using MannWhitney U test regarding Ki-67 and COX2 immunoreactivity

\begin{tabular}{|c|c|c|c|}
\hline Total Score & $\begin{array}{c}\text { Normal } \\
\text { mucosa } \\
\text { Mean } \pm \text { SD }\end{array}$ & $\begin{array}{c}\text { OKC } \\
\text { Mean } \pm \text { SD }\end{array}$ & p-value \\
\hline Ki-67 & $1.31 \pm 1.25$ & $3.93 \pm 1.81$ & 0.0001 \\
\hline COX-2 & $1.120 .93 \pm$ & $4.56 \pm 1.21$ & 0.0001 \\
\hline
\end{tabular}

$P$ value is significant when it is $\leq 0.05$

OKC showed significantly higher expression of both Ki-67 and COX-2 compared to dentigerous cyst ( $\mathrm{p}=0.01$ and 0.04 respectively) (Table 6).

There is positive correlation between the two markers in both dentigerous cyst and $\mathrm{OKC}(\mathrm{P}=0.02$ and 0.0001 respectively) as shown in table 7 .
TABLE (6): Comparison between dentigerous cyst group and OKC group using MannWhitney U test regarding Ki-67 and COX2 immunoreactivity

\begin{tabular}{|c|c|c|c|c|}
\hline \multicolumn{2}{|c|}{ Parameters } & $\begin{array}{c}\text { Dentigerous } \\
\text { cyst }\end{array}$ & OKC & P-value* \\
\hline \multirow{2}{*}{$\begin{array}{c}\text { Total } \\
\text { score }\end{array}$} & $\begin{array}{c}\text { Ki-67 } \\
\text { Marker }\end{array}$ & $2.37 \pm 1.54$ & $3.93 \pm 1.80$ & 0.01 \\
\cline { 2 - 5 } & $\begin{array}{c}\text { COX-2 } \\
\text { Marker }\end{array}$ & $3.43 \pm 1.63$ & $4.56 \pm 1.21$ & 0.04 \\
\hline
\end{tabular}

$P$ value is significant when it is $\leq 0.05$

TABLE (7): Correlation between Ki-67 and COX2 protein immunoreactivity in both dentigerous cyst and $\mathrm{OKC}$

\begin{tabular}{|l|l|l|}
\hline \multicolumn{2}{|c|}{ KI-67 Total score } & \multicolumn{1}{c|}{$\begin{array}{c}\text { COX-2 Total } \\
\text { score }\end{array}$} \\
\hline \multirow{4}{*}{$\begin{array}{l}\text { Dentigerous } \\
\text { cyst }\end{array}$} & $\begin{array}{l}\text { Correlation } \\
\text { Coefficient }\end{array}$ & $0.568^{*}$ \\
\cline { 2 - 3 } & Sig. (2-tailed) & .02 \\
\cline { 2 - 3 } & N & 16 \\
\hline \multirow{3}{*}{ OKC } & $\begin{array}{l}\text { Correlation } \\
\text { Coefficient }\end{array}$ & 0.914 \\
\cline { 2 - 3 } & Sig. (2-tailed) & 0.0001 \\
\cline { 2 - 3 } & N & 16 \\
\hline
\end{tabular}

\section{DISCUSSION}

COX-2 is a gene induced by growth factors, oncogenes and carcinogens and it is overexpressed in many human tumors including those of the oral cavity and head and neck (Juhng et al, 2004; Itoh et al, 2003; Sakurai et al, 2007; Renkonen et al, 2002)

The exact role of COX-2 in neoplastic development and growth has been contributed to its ability to resist apoptosis, promote cell growth, 
induce angiogenesis and enhance cell motility and adhesion (Wu et al, 2010).

The present study was carried out to elucidate the possible role of COX-2 in two odontogenic cysts (dentigerous cyst and $\mathrm{OKC}$ ) and correlate its expression with a well-known proliferation marker, Ki-67.

Regarding clinical data, the incidence of cystic lesions was more prevalent among male (53.1\%) and the lesions were more frequent in the mandible $(68.7 \%)$. These results are in accordance with those of Mesgarzadeh et al, 2008 whose findings showed increased incidence of $\mathrm{OKC}$ and dentigerous cyst in male more than female with the mandible being the most common site.

COX-2 and Ki-67 immunorectivity was evaluated using two parameters, staining intensity and index of positivity. Both lesions showed increased COX-2 and $\mathrm{Ki}-67$ expression in relation to healthy oral mucosa.

These results are fully compatible with those of Gadbail et al,2009 who detected higher proliferation index in OKC when compared to dentigerous cyst and healthy mucosa and it has been associated with higher intrinsic proliferation potential of $\mathrm{OKC}$, which may explain the local aggressive behavior of that lesion.

Our study showed significant difference in COX2 expression between dentigerous cyst and OKC. This may explain the invasive behavior of OKC when compared to less invasive clinical behavior of dentigerous cyst and this is supported by the notion that high expression of COX-2 is related to the aggressive behavior of oral tumors (Mendes et al, 2011).

The High expression of COX-2 was highly correlated with high expression of Ki-67 in the studied lesions.

The ability of COX-2 to stimulate cell proliferation can be explained by the fact that
COX-2 leads to synthesis of PGE2 with subsequent stimulation of EP4 receptors which leads to induction of the functional expression of early growth response factor 1 (EGR-1) which in turn controls Cyclin D1, a key regulator of cell cycle progression (Guillemot et al, 2001).

Furthermore, prostaglandin E2 inhibits tumor necrosis factor and induces IL-10 which has inhibitory effects on the immune system. It also appears that increased expression of COX-2 changes cell adhesion and response to regulatory signals and also it inhibits apoptosis (Mohan and Epstein, 2003; Williams et al, 2000; Itoh et al, 2003).

Our results in addition to available data from previously mentioned studies suggest that COX-2 may induce tumorgenesis in pathways affecting the proliferation of cells in dentigerous cyst and OKC.

\section{CONCLUSIONS}

COX-2 may serve as predictive biomarker of the clinical behavior of dentigerous cyst and $\mathrm{OKC}$ and this could lead to the development of new therapeutic pathways such as molecular targeted therapies of patients affected by these lesions.

\section{REFERENCES}

1. Adel K, John KC, Jennifer R, Takashi T, Pieter J. WHO Classification of Head and Neck Tumors. $4^{\text {th }}$ ed., Lyon, 2017.

2. Adelsperger J, Campbell JH, Coates DB, Summerlin DJ, Tomich CE. Early soft tissue pathosis associated with impacted third molars without pericoronal radiolucency. Oral Surg Oral Med Oral Pathol Oral Radiol Endod 2000;89(4):402-6.

3. Barboza CA, Pereira Pinto L, Freitas Rde A, Costa Ade L, Souza LB. Proliferating cell nuclear antigen (PCNA) and p53 protein expression in ameloblastoma and adenomatoid odontogenic tumor. Braz Dent J, 2005, 16(1):56-61.

4. Bratthauer GL. The Avidin-Biotin Complex (ABC) method and other avidin-biotin binding methods. Methods Mol Biol., 2010, 588: 257-270. 
5. Castealo JE, Bart RD, DiPerna CA, Sievers EM, Bremner RM. Lung cancer and cyclooxygenase-2. Ann Thorac Surg 2003;76(4):1327-35.

6. Crofford LJ. COX-1 and COX-2 tissue expression: implications and predictions. J Rheumatol Suppl. 1997 Jul;49:15-9.

7. Davies GL. Cyclooxygenase-2 and chemoprevention of breast cancer. J Steroid Biochem Mol Biol 2003;86(35):495-9.

8. Gadbail AR, Chaudhary M, Patil S, Gawande M. Actual proliferating index and $\mathrm{p} 53$ protein expression as prognostic marker in odontogenic cysts. Oral Dis 2009;15(7):490-8.

9. Greenhough A, Smartt HJ, Moore AE,Roberts H, Williams A, Paraskeva C, Kaidi A. The COX-2/PGE2 pathway: key roles in the hallmarks of cancer and adaptation to the tumor microenvironment. Carcinogenesis. 2009;30:377-86.

10. Guillemot L, Levy A, Raymondjean M, Rothhut B. Angiotensin II-induced transcriptional activation of the cyclin D1 gene is mediated by Egr-1 in CHO-AT(1A) cells. J Biol Chem. 2001;276:39394-403.

11. Hussain T, Gupta S, Mukhtar H. Cyclooxygenase-2 and prostate carcinogenesis. Cancer Lett 2003;191(2):125-35. 27.

12. Itoh S, Matsui K, Furuta I, Takano Y. Immunhistochemical study on overexpression of cyclooxygenase-2 in squamous cell carcinoma of the oral cavity: its importance as a prognostic predictor. Oral Oncol 2003;39(8):829-35.

13. Juhng SW, Kim HS, Min KW. Expression of cyclooxygenase-2 in adenocarcinomas of the uterine cervix and its relation to angiogenesis and tumor growth. Gynecol Oncol , 2004, 95: 523-529.

14. Kanekura T, Higashi Y, Kanzaki T. Inhibitory effects of 9-cis-retinoic acid and pyrrolidinedithiocarbamate on cyclooxygenase (COX)-2 expression and cell growth in human skin squamous carcinoma cells. Cancer Lett 2000;161(2):177-83.

15. Kawai N, Tsujii M, Tsuji S. Cyclooxygenase and colon cancer. Prostaglandins Other Lipid Mediat 2002;6869:187-96.

16. Kolokythas A, Karas M, Sarna T, Flick W and Miloro M. Does cytokine profiling of aspirate from jaw cysts and tumors have a role in diagnosis? J Oral Maxillofac Surg, 2012, 70: 1070-1080.
17. Li S, Miner K, Fannin R, Carl Barrett J, Davis BJ. Cyclooxygenase-1 and 2 in normal and malignant human ovarian epithelium. Gynecol Oncol 2004;92(2):622-7.

18. Manchana $T$, Triratanachat S, Sirisabya N, Vasuratna A, Termrungruanglert W, Tresukosol D. Prevalence and prognostic significance of COX-2 expression in stage IB cervical cancer. Gynecol Oncol 2006;100(3):556-60. 28.

19. Maryam S, Shahryar S, Sepideh S, Elham A, Nafiseh G, Ali B, Mostafa N. Immunohistochemical analysis of COX2 expression in dentigerous cyst, keratocystic odontogenic tumor and ameloblastoma: A comparative study. Dent Res J, 2015; 12(3): 278-284.

20. Masunaga R, Kohno H, Dhar DK, Ohno S, Shibakita M, Kinugasa S, Yoshimura H, Tachibana M, Kubota H, Nagasue N. Cyclooxygenase-2 expression correlates with tumor neovascularization and prognosis in human colorectal carcinoma patients. Clin Cancer Res 2000;6(10):4064-8.

21. Mendes RA, Carvalho JF, van der Waal I. Potential relevance of cyclooxygenase-2 expression in keratocystic odontogenic tumours - an immunohistochemical study. J Oral Pathol Med. 2011;40:497-503.

22. Mesgarzadeh AH, Esmailzadeh H, Abdolrahimi M, Shahamfar M. Pathosis associated with radiographically normal follicular tissues in third molar impactions: a clinicopathological study. Indian $J$ Dent Res 2008;19(3):208-12.

23. Miyata Y, Koga S, Kanda S, Nishikido M, Hayashi $\mathrm{T}$, Kanetake H. Expression of cyclooxygenase-2 in renal cell carcinoma: correlation with tumor cell proliferation, apoptosis, angiogenesis, expressions of matrix metalloproteinase-2, and survival. Clin Cancer Res 2003;9(5):1741-9.

24. Mohammed A, Hitoshi M, Takahiro T, Sheng R. Odontogenic epithelial proliferation is correlated with COX-2 expression in dentigerous cyst and ameloblastoma. Experimental And Therapeutic Medicine, 2017, 13: 247253.

25. Mohan S, Epstein JB. Carcinogenesis and cyclooxygenase: The potential role of $\mathrm{COX}-2$ inhibition in upper aerodigestive tract cancer. Oral Oncol. 2003;39:537-46.

26. Neville BW, Damm DD, Allen C, Bouqout JE. Oral and Maxillofacial Pathology. $3^{\text {rd }}$ ed. Missouri: Saunders; 2009; pp. 116-20. 590-2, 594-6, 678-707. 
27. Nozoe T, Ezaki T, Kabashima A, Baba H, Maehara Y. Significance of immunohistochemical expression of cyclooxygenase-2 in squamous cell carcinoma of the esophagus. Am J Surg 2005;189(1):110-5.

28. Philipsen HP. Keratocystic odontogenic tumour. In: Barnes L, Eveson JW, Reichart P, Sinransky D. (Ed.) Head and neck tumours, WHO classification of tumors. $5^{\text {th }}$ ed., Lyon: IARC Pres, 2005, p.306-7.

29. Regezzi JA, Sciubba JJ, Jordan RCK. Oral pathology: clinical pathologic correlation. $5^{\text {th }}$ ed., Philadelphia: Saunders, 2008.

30. Renkonen J, Wolff H, Paavonen T. Expression of cyclo-oxygenase-2 in human tongue carcinoma and its precursor lesions. Virchows Arch, 2002, 440: 594-597.

31. Sakurai K, Urade M, Noguchi K, Hashitani S, Takaoka K, Segawa E, Kishimoto H. Prognostic significance of cyclooxygenase-2 and DNA topoisomerase II alpha expression in oral carcinoma. Head Neck, 2007, 29: 1002-1009.
32. Shibata Y, Asaumi J, Yanagi Y, Kawai N, Hisatomi M, Matsuzaki H, Konouchi H, Nagatsuka H, Kishi K. Radiographic examination of dentigerous cysts in the transitional dentition. Dentomaxillofac Radiol 2004, $33: 17-20$.

33. TelliezA, Furman C, Pommery N, Henichart J.Mechanisms leading to COX-2 expression and COX-2 induced tumorigenesis: topical therapeutic strategies targeting COX-2 expression and activity. Anti-Cancer Agents in Medicinal Chemistry. 2006 May;6(3):187-208.

34. Williams CS, Tsujii M, Reese J, Dey SK, DuBois RN. Host cyclooxygenase-2 modulates carcinoma growth. J Clin Invest. 2000;105:1589-94.

35. Wu WK, Sung JJ, Lee CW, Yu J, Cho CH. Cyclooxygenase-2 in tumorigenesis of gastrointestinal cancers: An update on the molecular mechanisms. Cancer Lett, 2010, 295: 7-16.

36. Zha S, Yegnasubramanian V, Nelson W, Isaacs W, De Marzo A. Cyclooxygenases in cancer: Progress and perspective. Cancer Lett., 2004, 215: 1-20. 